\title{
Impact of Hollywood movies in the expansion of English as global language.
}

Impact of Hollywood movies in the expansion of English as global language.

Edison Gerardo Llerena Medina. ${ }^{1}$ \& Carlos Patricio Rodríguez Hurtado. ${ }^{2}$

Recibido: 08-12-2017 / Revisado: 03-02-2018 Aceptado: 11-03-2018/ Publicado: 01-04-2018

\begin{abstract}
.
DOI: https://doi.org/10.33262/cienciadigital.v2i2.117

The American's films are not only viewed in the United States, but they are massively viewed all around the world, and the audience for Hollywood movies have increased greatly. Most of the films go smoothly into viewers because of their attractive storytelling. This phenomenon has contributed powerfully to the expansion of the American Culture, turning it into a more relevant source to spread out the language through out the world. A film is seen as a medium that reaches a huge amount of audience with the same message, in that way, films have the ability of capturing imagination, and developing creativity, because movies contain motion pictures and sound.
\end{abstract}

On the other hand, America is the super power in the world, then its major goal is to imperialize the world again by using a soft tool like the films, which transfer American values and customs indirectly as well as the language. The promotion of the American culture through Hollywood movies may make other social groups decide whether to fear or favor the promise of Americanization and a globalized planet.

Keywords: Hollywood movies, communication, global language, culture

\footnotetext{
${ }^{1}$ Universidad Técnica de Ambato, Centro de Idiomas, Ecuador, eg.1lerena@uta.edu.ec
} 2Universidad Técnica de Ambato, Centro de Idiomas, Ecuador, cp.rodriguez@uta.edu.ec 


\section{Resumen.}

Las películas Americanas no solo se ven en los Estados Unidos, sino que se ven masivamente en todo el mundo, y la audiencia de las películas de Hollywood ha aumentado enormemente. La mayoría de las películas se transmiten sin problemas a los espectadores debido a su atractiva narración de historias. Este fenómeno ha contribuido poderosamente a la expansión de la cultura estadounidense, convirtiéndola en una fuente más relevante para difundir el idioma en todo el mundo. Una película se ve como un medio que llega a una gran cantidad de público con el mismo mensaje, de esa manera, las películas tienen la capacidad de capturar la imaginación y desarrollar la creatividad, ya que las películas contienen imágenes en movimiento y sonido.

Por otro lado, Los Estados Unidos de America son considerados como la superpotencia del mundo, entonces su principal objetivo es volver a imperializar el mundo mediante el uso de una herramienta suave y sencilla como las películas, que transfieren los valores y las costumbres estadounidenses indirectamente, así como el lenguaje. La promoción de la cultura estadounidense a través de las películas de Hollywood puede hacer que otros grupos sociales decidan si temer o favorecer la promesa de americanización y un planeta globalizado.

Palabras Claves: Hollywood movies, communication, global language, culture

\section{Introducción .}

The present paper aims to analyze relevant aspects related to the cinema through its history and the influence of English language over Hollywood movies. English language has become a powerful tool regarding to direct actions of people remarks (Maisuwong, 2012:1). This fact about cinema is an art. Consequently, the "cinemathography" word emerged from English which means movements of objects related to expose and face to the audience. In addition, the "cinemathography" word is related to real or subjective events which attract the eyes and ears of the audience, the performance of actors and actress by demonstrating their hard working, talent and capacity in a memorable manner. According to Chandra (2015:16), American films have brought the audience a critical culture, values, political messages regarding to freedom of expression and lifestyle through the use of English language.

The accent of voice in the cinema plays an important role in the impression of the audience due to the fact that the accent of voice produces particular effects such as the pronunciation and intonation to meet the message. According to Gluszek \& Steffens (2012:14), the pronunciation and intonation are of relevant importance because the message could be misunderstood if it does not use the correct pronunciation and intonation. Jenkins (2009:2) 
states the case of Polish people, in which stereotypes can be given to people from different linguistic conditions.

The entertainment has been an important sector, where new technologies have altered the nature of home and public entertainment. However, its increase becomes the most powerful tool to transmit communication worldwide. Consequently, it has been replaced for new objects, artifacts, new engines to manipulate without the assistance of human being. On the other hand, the English language has done certain fresh directions for the development of this language due to the descriptions, transcriptions and translations made on the films. Crystal, (2003:98) argues that the incidence of technology in today's world has altered the lifestyle at home but also has influenced in the entertainment settings due to the fact that it has given another distinction to the way of communicating and transmitting the message to fellows during last decades.

During last times, Films became a reflection in the society regarding to the present and past time events. Furthermore, the events occurred in the past have constituted to create awareness on facts that have happened along the history and on the events, that are happening daily. Shah (2011:34) emphasizes on the importance of movie as part of art, in which actors and actresses recreate situations, events occurred in the past and in the present to express their feelings, emotions and desires freely. Additionally, these facts make people reflect on certain behaviors of human being. For instance, principles such as respect, honesty, and responsibility clear rule people to live harmoniously in the society.

Since the 1920s, the technology was introduced in movies which have created great importance due to the sounds of the English language. The sounds have created dominance in the language and the language suddenly came to dominate the movie world. Crystal (2003:98) defines the importance of this art. Since the beginning of cinema, technology was introduced to feature the sound effects of movies. Moreover, English language and its expansion have contributed in the increased number of annual productions of series addressed to huge audiences. English has become a huge impetus in the industry of films making of Hollywood movies a success worldwide.

Furthermore, the achieved importance in the Hollywood art is enormous due to the fact that during the history of movies, there has not been another language besides English that had reached the impact on Hollywood movies up until these days. In 2002, according to the lists in the British Film Industry (BFI) and television handbook over 80 percent of all feature films are given a theatrical released in the English language (Crystal, 2003: 98). This research work intends to explore the relevant impact of the English language over Hollywood movies and relate them to the Historical Background of cinema, the cinema in the Chinese, Indian and Japanese countries and the performance of Hollywood movies in the expansion of 
English as a global language as well. Furthermore, the digital and silent era are being analyzed. Finally, this research work purposes to analyze the evolution of editions, sounds, librettos of actors and actresses, the role of the audience, Oscar awards and English as the language of the cinema.

\section{Content DevelopmentHistorical Background of Cinema.}

English language has been associated with the film culture for a long time. Although, at the beginning it was French language which gave the early stimulus to commercial and artistic development. France was the first country where the artistic and commercial industry achieved its departure point setting (Clee, 2009:7). However, the film industry has evolved from 1895 as the culture film industry and it has been associated with the English language.

During the First War one, the industry of films expanded from the European to the American Continent. Moreover, the industry of films found home in Hollywood, specifically in California where the film industry formed as the base for the great studio settlement (Clee, 2009:7). Later in 1920, the sound was added to the films with other features such as digital manipulation, tridimensional level and 3D effects which became dominance in the world of films. Since this fact, the art has grown in other places where English films have achieved a considerable status.

In 1997, Walt Disney created the first animated film in English language. This film was 'Lippi Green's' which contained certain relevant approaches related to the English Language. According to Bleichenbacher (2008: 681), 'Lippi Green's' film contained enough English literature focused on a number of features such as audiovisual translation, sociolinguistic approaches and even more English linguistic ideology in cinema. Moreover, 'Lippi Green's' was produced in certain broken English in order to draw the audience attention and implement a linguistic discrimination. Consequently, it gave place to linguicism, a phenomenon named filmmakers.

According to Bleichenbacher (2008:681), filmmaker created a multilingualism difference between the real and subjective world. The first filmmaker was focused on films in terms of real authenticity and fidelity. Moreover, fiction is a classification of films based on a specific imaginary story or scenario which arise in the human mind.

The evolution of the language in the cinema found two fields as: the silent and real film. After the sound appeared the montage, which improve the realism. In 1928, this kind of genre achieved the its artistic peak which has criticized by realism.

Furthermore, between 1920 to 1940 focused two aspects those who put their faith in the imagen, and those who put faith in the reality. Furthermore, two categories those were related 
to the plastic and the imagen and those represent the montage resource. The first related to the plastic represented the style of set and make-up, lighting and the framing of the shot, regarding to the montage initially known form masterpieces of Griffith that gave birth to film as an art and come to be the animated photography, in short, creating a language (Bazin , 1967:194).

In addition, the cinematic language that emerged between 1930 - 1940, largely driven by the American Hollywood system which consisted of major film types: The American comedy, the burlesque film, the dance and vaudeville film, the crime and gangster film, Psychological and social dramas, Horror or fantasy films and the western films. In 1940s-1950s comes the real driver of cinematic language's development when new people and themes were explored and later take relevance more in the subjective form but the style (Bazin , 1967:194). Furthermore, the evolution of this genre, the cinema achieved major force and impetus as in the maturing of different kinds of drama, the drama inherited from the silent film and the stabilization of technical progress.

English Language was used to transmit several films as fast as they became universals worldwide. A number of films became universal because titles could easily be translated and distributed internationally. Although there was a parochial quality to the American production, the relatively high budgets, technical sophistication, narrative pace, and emphasis on likable screen personalities made them popular wherever they were shown. Pierce (2013:73) states that the language has been a main part in the development of films through history which become universals thanks it has been translated its scenes and the producers and actors have achieved to join great economical and have gone perfect over and over again.

\section{Hollywood, the American Image and the global film industry.}

Hollywood, named also as the United States' National film industry created the biggest companies such as Paramount, Warner Bros, Columbia, and Universal. According to Finler (2003: 9), they were addressed to the TV, later moved into music. In 1969, those companies were subsided to 1980 those companies it moved to the television and Cinemax. All long time thanks to the World War Second this industry fell down.

On the another hand the streets of African continent specifically in Nigeria it could observe people sees any foreign films that it is not Chinese and Indian as American is merely a perception this has passed the dad-named of developing countries because the exploitation has come from industrialized countries. Ali Ibbi (2014: 94) argues that it created a domain system of global economic relations, this dependence it has given thanks to the incorporation of technology and the media due the expansion achieved of the language with continuous flow of western cultural products into poor countries. 
Although the films continued appearing, the Americans filmmakers their impact pales in comparison with that of Hollywood's output on the rest of the world (Kunste, 2014:97). Certainly, the films around the world continued moving for everywhere but only just the American films achieved great splendor. Hollywood has succeeded in selling America to the world and America was seen as a utopian society that is devoiced of errors. After the September 11th terrorist attacked on America, some local traders were involved in a heated argument that it was not America.

The imagen of Hollywood has been a sold imagen in whole world. America obviously, a society with many defects mainly when the twin towers fell down, this country begun to have the worst imagen specially those countries involved in this fact (Freeland, 2014: 96). Hollywood, it has been an enterprise known in everywhere admired their values and the world audience it has converted in the consumers of products after to watch their movies, the culture of eating low carb food in American movies, and the expansion that achieved thanks to the language has spread its domain.

Moreover, American ideology is a medium mass of communication, inside movie industry it has converted in Hollywoodization, there were not more the copy become this fever affecting them to Asian market who has tried to imitate the same style, dressing even the name of Hollywood but moviemaking has not achieved to replace to the American brand (Fair, 2006:78). American cinema industry has known to match its territory and the entertainment it has not been the exception the movie, TV, segments, for this influence has started to engage the foreign language with foreign entities.

\section{Silent Era: Portraits, Painting and photography.}

It is a philosophical art; it has focused in the objective and subjective part, in order to describe two categories, the revelatory and creative category of the artistic expression. Freeland (2007:95-108) states that the first artistic expressions have referred to the works and typology, when remark the speaking of an imagen's power to show a person according the accuracy, testimony of presence, emotional characterization, or revelation of the essential, in other words is the strongly connection the painter with his model. The portraits were made in funerary paintings by Roman Egypt in order to preserve the cults of the dead.

Regarding to the art of portraits in photography has been linked to the realism and transparency, but is the art less movement, less life, in order to show realistic and revealing than paintings but this has not left to be a static art. According to Kunste (2014:2-22), an apparatus has been designed in 1893 through a projector looked like as mobile picture called Kinetoscope object, it has allowed to view the movies only one person, later it used a camera, printer and projector of film helping to view a huge group. In the last time, the colors have taken force, the techniques used in lantern glass slides coloring, using fine brushstrokes 
directly onto the film stock. Another technique applied in 1906 Stencil colored in Paris workshops where have been done mainly using stencils.

\section{Digital Era.}

The technology it has taken the planet and the changes notorious have provoked twenty years ago, the internet arrived to our lives become powerful tool, and its presence has noted in commercial trades, industry, society and relationship of human arts, cinema, and being through social networks. Nowadays the technology it has increased the result are a connected planet, a global community environment. In the cinema, the huge stars drive a current technology in their spots, gooiness, scenes, and the cameras employed are the last generation in 3D (Towers, W. 2016:8).

The silent era was dominated by the mythology and filmmakers narrated many stories of their childhood using motion pictures as a medium of expression, this type of genre arrieved to cover certain topics related to the society films as a medium of expression. Gradually the technology made it possible to make talkies and the first film in 1931. According Alam Ara made the first film which was screened in Bombay, the creit of producing the first color movie also went to Sir Ardeshir. In 1937 to 1940 have taken historical style. Kausar \& Pandey (2016:56) state that films are made with a rapid speed and cost of film-making has changed the production process completely. On the another hand the films are seen as a big budget and currently are being used the cheap technology has provided wings to the new film competing makers as well

\section{Hollywood Film Industry in India.}

Hollywood is called Bollywood in India, a language of cinema industry developed in this part of world, the facts have pointed out it has produced around of 900 films which become the largest industry of world but the revenue has been lower, due to the content quality, competition from Hollywood has come to effect it (Young, 2012:4).

The Asian industry it has achieved remarkable importance in South Asia, since mind 90s has grown thanks to Paramount whom shared 0.6 incomes from Hollywood and this type of industry has continued growing in a 10-15 per year. Mc Donald \& Wasko, (2008:344) mention the case study of the Hulk film achieved an equivalent to Universal's highest opening weekends 214,000 gross face 81 Indian theaters. X-men united that obtained 352,000 grass face 132 during opening weekend, this thanks to the English language that become a gap or an opening in the world cinema.

The Hollywood's history in India has crossed three overlapping trajectories consolidation, competition and collaboration. Govil (2008:21) remarks that from World war one India has 
shared of world USA film export doubled to four percent of total film, were the European films storages and stock rationing to consolidate in the area. Example in 1916 was stablished Universal the first Hollywood studio where were arose around of 150 films per year, and being in India it has arose 100, it was so the influence of English as a Global language has had huge importance of Hollywood has transcended and spread to India (Sunder , 2011).

In 1940 the American film markets, fell down around of 45 percent but was after world war one, where these begun to earn of Indian's total box-office revenues. Govil (2008:25) mentions that during the 1960s American films were exclusively screened in English, thanks to adoption of this language in the Southern Indian State helped raise Hollywood's regional revenues.

\section{Hollywood Film Industry in China.}

The Chinese language has been diverse and has had seven variety of dialects as: Mandarin, Wu, Xiang, Yue, Kejia, Gan and Mind divided in sub-groups and sub-dialects further divided into vernacular and accents the same has used in different settings as an official language, into teaching, the role of a global language's special (Jeffrey , 2010:52-58)

The Chinese movies have never been an independent art, during the war era it was used in campaigns as political tool to lead. In the early ages, two thousand ago, the cinema was empathized by mobile shadows and images. Lent \& Zhengxing(2000:22) mentions that in 1896 cameramen-showman were introduced along several audiences as: Shanghai, Beijing, Great Britain, United States, Spain, Japan. Furthermore, it was incorporated the electric shadows art, and were interpreted, through magician acrobat and juggler or fireworks. In 1902 Fengtai formed the first Chinese film as: The romance of Three Kingdoms, The Dream Lovers of Peony Pavilion tales were interpreted, written and directed by Chinese and English language.

A couple years after it given chance to the artistic exploration and ideological expression, with features of societal values, ethic, moral, war, history and love, respect for elders, also has highlighted the farce-comedy characterized by Charles Chaplin Green (2017:4) refers to the Norte American comic based in the behavior and personality which emphasized, moral lesson and punished evil. In silent movies the English language, was evident its participation because the audience depended of a narrator who interpreted the English tittles on the screen.

According to Kurosawa (2009:2-3), the huge amount ranges of Chinese films achieved a considerable range in this country due to the performing of Chinese actors and actresses who performed the movies in Chinese and English language. Furthermore, Hang (2010:1) declares that there is a number of cutting-edge forms and cultural production about some given materials, lectures, artistic modes, including formalism, historiography, drama, and screening available in English. 


\section{Hollywood Film Industry in Australia and New Zealand.}

The cinema in Australia and New Zealand converted the culture distinctively due to the development in the political, economic and cultural settings. The national cinema became a main part because privileged certain values focused to atomize the Indi dualism to help the community (Mayer \& Beattie, 2007: 3). Nowadays, science, technology and entertainment have changed continuously in the Australian cinema industry regarding to audiences, digital videos, cultural expressions, multiple platforms, social net workings and film makings which have become a serious problem for the government and state institutions where a number of funding models have increased for almost twenty years.

Consequently, a new era for Australian and New Zealand cinema have overcame in the screen industry in which the content and commercial viability have increased. According to Ryan (2010:1-6), Knowing film it has come to cover the 40 percent of local production, the screen Australian effectiveness has had to see according the strategy and diversity, and how the language it is the main support in the development of this art, joined to the English language as mother tongue the cinema of industry become a strong part to the development.

\section{Oscars and Celebrities .}

It was the first Academy Awards, created in 1929 of the Hollywood Roosevelt hotel with just over 270 guests attended to the event, it was not always a rewards place. According to Guok (2012:45), during fifteen years' awards presentation there were banked affairs and the custom to present the statuettes were discontinued after 1942, three years later it delivered in discontinued way. In 1949, the $21^{\text {st }}$ awards for the next eleven years. The NBC and TV radio networking have twenty-five Oscars ceremonies is continued for realizing for a dozen years. Gouk (2012:45) highlights that since 2002 the academy awards have been held at the Dolby, formally Kodak at Hollywood and Highland being the early the center.

The first fifteen statuettes were presented for directing and writing later was reducing at seven as: acting, outstanding pictures, jazz, singer, producers, directing, writing and starting. Ryan (2010:9) states that special effects were introduced in 1939 but 1963 awards were split in twos: sounds, effects, special visual effects, recognized to the best sound effect. In 1968, the awards ceremony was postponed for Dr. Martin Luther King who was assassinated. Later the delivery of statuettes was postponed because of assassinated attempt on Ronald Reagan president.

The Hollywood industry deliver around of nineteen academy awards of merit to the person, biologist, environmentalists, scientists, peace people, Chemistries, literates, Writings, directing, actors and actress that have achieved some merit in any discipline. Sandler (2015: 16) states that to be selected actors and actresses have been subjected strongly rules among awards deliver in the ceremony account the following nominations acting, award, animated 
feature fil award, cinematography award, costume design award, directing award, documentary award, film editing award, foreign language film award, makeup and hairstyle award, music, best picture, production design, scientific and technical award, writing, governor's award among others.

The English language as a global language as dominance tools in the film industry plays a main role because is a characteristic which it has moved to the celebrities in this medium. Kurosawa (2009:2-3) emphasizes that actors, actresses, celebrities philosophers, Chemistries, Literates, Directing triumph to achieve the fame, necessarily they must domain the universal language, great cineastes must know in a deepen way this language because the films produced which librettos are in English, the governs to sign important peace agreement to gain a main statuettes the English language is the main resource to get negotiations is in English, for this reason this language is that move to the world and it will continue do it in the future.

\section{Case studies.}

\section{Case Study N 1: X-Men Movie.}

X-men Film was first produced in 2009. It obtained 352,000 grass face 132 during opening weekend, this thanks to the English language with vocabulary of easy comprehension which improve the English vocabulary through of idioms and common jargons, constituting the best way to learn everyday language that become a gap or an opening in the world cinema (Mc Donald \& Wasko, 2008:344).

\section{Case Study $\mathbf{N}^{\circ}$ 2: English Video-Conferences.}

According to Yasumoto, (2014:3) the video-conference through English lectures, have served as a medium of learning for Chinese students, in order to benefit them and spread the language in a good way, is the option taken by the University of Sydney and Japan students through video-conferencing. The course content includes newspaper reading, video analysis, discussion and research presentation, and skype video-conference on subjects as Media and popular culture it has allow them participating in this option have an intermediate level of English language, in order to gain scholarships and cultural exchange.

Watching movies is a great way for you to improve your English, especially listening and speaking skills. Films are not usually created for English language learners -they are made for native English speakers. Hang (2010:1) declares that the language is exactly how people hear it in real life -it is spoken quickly, with native accents and pronunciation and using many idioms and colloquial expressions. Choosing a film to watch that is suitable for the level of English can be difficult. If your level of English is quite low, choose a movie that you have already seen or a movie made for children which uses simpler language (for example, Pixar films). 


\section{Case Study $N^{\circ}$ 3: Science Fiction Movies-The Lord of the Rings, Star Wars and Transformers.}

According to Winerta (2007:5), the use of linguistic stereotypes in Hollywood movies. It investigates whether attitudes towards English dialects found in studies on perceptual dialectology are reflected in the selected movies and discusses the notion of linguistic identity and how standard and nonstandard speech, respectively, are used symbolically to emphasize features of characters in eleven movies from three different movie series.

The Lord of the Rings (1978), Star Wars and Transformers, with a main focus on syntactic and phonological dimensions Anderson, (2009:1), it finds a correlation between standard speech and features of competence and wisdom, and nonstandard speech and features of solidarity, sociability and traits of stupidity and humor. Moreover, very specific perceptions of certain varieties of English are probably utilized as amplifiers of equally specific characteristics of some characters.

The use of dialects and accents in these movies is probably intentional rather than coincidental.

\section{Case Study $N^{\circ}$ 4: Avatar Movie.}

Avatar was an American film on 2009 which wrote and directed by James Cameron. This film spent \$237million. By using 3D technology, this film has reached high attention from many people. As human being, we have to care about our environment. Avatar movies script was about conversation among the characters. Winerta (2007:1-14) considers that the data were words, phrases, and clauses that contain politeness strategies in requesting of the conversations in Avatar's movie which used English as the language.

The data got from the conversation among all characters in the movie of Avatar, data analyzed based types of politeness strategies which had requesting form.

\section{Case Study $\mathbf{N}^{\circ}$ 5: Titanic Movie.}

Titanic (1997) is one of masterpiece movie in the film industry which won eleven Oscars of the academy and was produced in United States. In addition, Kurosawa (2009:5) mentiosn that Titanic is a movie about a disaster romance movie directed, written, produced and edited by James Cameron about the sinking of Titanic ship. Moreover, it also tells about the forbidden love story between Rose and Jack who board this ship. This research uses Titanic movie because it has dialogues that there is no overt link between the utterances, however; the characters can do the dialogue in coherent way. 
The English language aims in this film speaking a language is performing speech acts, acts such as making statements, giving commands, asking questions, or making promise. Kusuma Maghfira (2014:1) mentions that while doing speech act, people can use direct and indirect speech act. In making utterance, people sometimes use implicit meaning and sometimes use explicit meaning, which in depend on the condition and situation of the speakers and hearers.

\section{Analysis.}

Nowadays is the used as a Global language in the cinema, because this language has emerged the cinematography in birder to have direct or subjective contact with the eyes, ears and the audience regarding with talent, hardworking in order to present to the audience, critical values and even lifestyle. English is significance and lifestyle inside of pronunciation, accent and the dialect because the message will have perceived better if it is associated with a similar social group. Furthermore, the pronunciation the accent play a role important inside of impression formation as it evokes particular associations with the rest.

During the Hollywood film history, a number of English movies have spread over the world due to the fact that Hollywood movies are preferred by the audience because of its effects, features, content, and entertainment addressed to the audience of different ages and times. Most of these films and productions have spread the English Language worldwide taking the status of a tool for entertainment and for learning English as well. This fact is demonstrated in the following chart that shows how English was and is spread up to these days.

\section{Chart 1. Hollywood Movies to spread English Language.}

\begin{tabular}{|c|c|c|c|c|c|}
\hline $\begin{array}{l}\text { Case } \\
\text { Study }\end{array}$ & Movie Title & Year & $\begin{array}{l}\text { Countr } \\
\text { y/City }\end{array}$ & $\begin{array}{l}\text { Director/ } \\
\text { Producer }\end{array}$ & Contribution in the spread of English Language \\
\hline 1 & $\begin{array}{l}\text { X-men } \\
\text { Movie }\end{array}$ & 2000 & $\begin{array}{l}\text { United } \\
\text { States }\end{array}$ & $\begin{array}{l}\text { Bryan } \\
\text { Singer }\end{array}$ & $\begin{array}{l}\text { Contains English vocabulary of easy comprehension } \\
\text { through the use of idioms and common jargons. } \\
\text { A means to learn everyday English language in the } \\
\text { cinema world. }\end{array}$ \\
\hline 2 & $\begin{array}{l}\text { English } \\
\text { Video- } \\
\text { conference }\end{array}$ & 2014 & China & $\begin{array}{l}\text { Chinese } \\
\text { Film } \\
\text { Directors }\end{array}$ & $\begin{array}{l}\text { Content related to newspaper reading, video analysis, } \\
\text { discussion, research presentation, skype video- } \\
\text { conferences in English addressed to Chinese students } \\
\text { to obtain a scholarship and a cultural exchange } \\
\text { Help Chinese students to get an intermediate level of } \\
\text { English language. }\end{array}$ \\
\hline 3 & $\begin{array}{l}\text { Lord of the } \\
\text { Rings }\end{array}$ & 1978 & $\begin{array}{l}\text { New } \\
\text { Zealand }\end{array}$ & $\begin{array}{l}\text { Peter } \\
\text { Jackson }\end{array}$ & $\begin{array}{l}\text { Focus on syntactic and phonological dimensions. } \\
\text { Correlation between standard speech and features of } \\
\text { competence and wisdom. } \\
\text { Nonstandard speech and features of solidarity, } \\
\text { sociability and traits of stupidity and humor. }\end{array}$ \\
\hline
\end{tabular}




\begin{tabular}{|c|c|c|c|c|c|}
\hline & Star Wars & 1977 & Algeria & $\begin{array}{l}\text { George } \\
\text { Lucas }\end{array}$ & $\begin{array}{l}\text { Perceptions of certain varieties of English language } \\
\text { spoken by characters. }\end{array}$ \\
\hline & Transformers & 2007 & England & $\begin{array}{l}\text { Michael } \\
\text { Bay }\end{array}$ & $\begin{array}{l}\text { Use of extravagant dialects and accents to learn } \\
\text { English. }\end{array}$ \\
\hline 4 & Avatar & 2009 & $\begin{array}{l}\text { United } \\
\text { States }\end{array}$ & $\begin{array}{l}\text { James } \\
\text { Cameron }\end{array}$ & $\begin{array}{l}\text { English conversations among all characters. } \\
\text { Words, phrases, and clauses contained politeness } \\
\text { strategies in requesting. } \\
\text { Conversations data analyzed based on types of } \\
\text { politeness strategies in requesting form. }\end{array}$ \\
\hline & & & & & English as the original language of the movie. \\
\hline & & & & & Performing speech acts \\
\hline & & & & & Making statements \\
\hline & & & & & Giving commands \\
\hline 5 & Titanic & 1997 & United & James & Asking questions \\
\hline & ก 1 & & States & Cameron & $\begin{array}{l}\text { Making promise used through direct and indirect } \\
\text { speech act. }\end{array}$ \\
\hline & & & & & $\begin{array}{l}\text { Use implicit meaning and sometimes explicit meaning } \\
\text { in related to utterances. }\end{array}$ \\
\hline
\end{tabular}

Source: Created by the author based on Mc Donald \& Wasko, 2008.

Additionally, huge values have achieved in the world by the delivering of the Oscars awards around the nineteen academies of merit of the person, biologist, environmentalist, scientists, peace people, Chemistries, literates, writings, directing. In reference to Sandler (2015:16) actors and actress have achieved some merit in any discipline to be selected they have been subjected strongly rules among awards deliver in the ceremony account. For instance, the following nominations acting awards, animated feature film awards, cinematographic awards, editing, foreign language film, makeup, hairstyle, music, best picture, production design, scientific and technical awards, governor's awards among others.

\section{Conclusiones.}

- The impact of Hollywood movies in the Expansion of English as A Global Language is strongly related due to the fact that most of the Hollywood movies are transmitted and preferred in English language worldwide. The technology has influenced Hollywood movies in order to improve the media, communication, entertainment and the daily life of the audience by using English as a means of spreading the language and the culture. Hollywood movies have identified the importance of art by using English as the official language on their performance.

- Hollywood movies have reached a strongly status in the film industry due to the fact that Hollywood movies consider English as the global language used worldwide. Thus, there is not another language besides English which have increased the huge audience ranges of Hollywood movies as it has done since its settlement. The features 
Hollywood movies create are of relevant importance for the preference of the audience mainly because the English language is preferred in their production.

- Furthermore, the technology on Hollywood movies has permitted English to spread around the world in an entertainment form to enjoy and to learn English as well. The audience find Hollywood movies interesting because of their features such as digital manipulation, tridimensional level and 3D effects. The sounds of the English Language catch the audience attention as well, especially the tone of voice of actors and actresses which sound appealing for learning English.

- In addition, Hollywood movies took a considerable status in European countries such India, China and New Zealand where English was spread. People from those countries prefer Hollywood movies in the English version because it is their original production language. Hollywood movies have influence in digital videos, cultural expressions, multiple platforms, social networking around these countries. Hollywood movies have also been a means of transmitted a culture by using English as the global language.

- Furthermore, Hollywood films such as X-men, The Lord of the Rings, Star Wars, and Transformers including English video-conferences have contributed in the expansion of English worldwide. The English language used in these movies has stimulated people to learn English due to their vocabulary of easy comprehension, use of idioms, common jargons demonstrating features of solidarity, sociability and traits of humor and in other cases of stupidity. Moreover, these Hollywood movies provide perceptions of certain varieties of English language spoken by the characters.

- Hollywood movies demonstrate a gap between the subjective fictional world and objective real world where actors and actresses sometimes live real events. On the other hand, Hollywood movies create a fantasy world to express a freely message to internalize the life throughout dramatization and performance. To conclude, Hollywood Film Industry has transmitted a number of films during its history which have become universal because of their titles, translations and expansion of the English as a global language.

\section{Referencias bibliográficas}

Ali Ibbi, A. (2014). Hollywood the American imagen and the Global Film Industry. ResearchGate , Cinec Cinema Journal, 94. doi:DOI 10.5195/cinej.2013.81

Bazin, A. (1967). What is cinema? (Vol. 1). Brekeley and los Angeles, California, London, England: University of California press, 194 
Bleichenbacher, L. (2008). Multilinguialism in the movies. Sociolinguistics studies, 681.

Chandra Guru, M. (2015). Critical Study on History of International Cinema. (I. Standard, Ed.) International Journal of English Language, Literature and Humanities., III, Issue VII, 1-16.

Clee, H. (2009). The influence of English fil media on the Finnish language. The role of English in Finnish film magazine, 7.

Crystal, D. (2003). English as a Global Language (second ed.). United States of America: Cambridge University press, 98

Finler, J. (2003). The Hollywood History. London: Wallflower press, 9

Freeland, C. (2007). Portraits, Paintings and Photography. Springer, 95-108.

Govil, N. (2008). India:Hollywood's Domination, Extinction and Re-animation(With thanks to Jurassic Park). Australia: UK copyright, designs, and patents act, 1988, 21-25

Jeffrey , G. (2010). A Comparison of the Global status of English and Chinese towards a new global Language? (Vol. 27 ). United Kingdom: Cambridge University press. doi:10.1017/S0266078411000149, 52-58

Kunste, B. (2014). Digital Colour Restoration of Applied Colour Silent Era Films: Discussions on Dilemmas, Practice and Digital Presentation. 2-22.

Kurosawa, A. (2009). The man is genious. (S. H. Lim, Ed.) Journal of Chinese Cinema, 3- 2.

Lent, J., \& Zhengxing, F. (2000). The International movie industry. (K. Gorham, Ed.) United States: Southern Illinois University press, 22

Maisuwong, W. (2012). The Promotion of American Culture through Hollywood Movies to the World. International Journal of Engineering Research \& Technology (IJERT), 1 Issue 4, 1.

Mayer, G., \& Beattie, K. (2007). The Cinema of australia and New Zealand. Great Britain: Wallflower press, 259

Mc Donald, P., \& Wasko, J. (2008). The Comtemporary Hollywood film industry. Main Street, Malden: UK Copyright,designs and Patents Act 1988,344

Pierce, D. (2013). The Survival of American Silent features film. Washington. D.C: Council on Library and Information Resources, 73

Ryan, M. (2010). Film, Cinema and Screen. Qut, 1-6.

Sandler, M. (2015). PR and Politics at Hollywood's Biggest Night:. Media Industries Journal 2.2 (2015) ISSN: 2373-9037, 16.

Shah, V. (2011). The role film in the society, 34 
Towers, W., W. (2016). Digital Media and Society Implications in a Hiperconnected Era. World Economic Forum Shaping the Future Implications of Digital Media for Society, 8 Cologny/Geneva/Switzerland.

Young, E. (2012). Film industry in India "New Horizons". Media and Entertainment industry in India, 4. 
Para citar el artículo indexado.

Llerena E. \& Rodríguez C.. (2018). Impact of hollywood movies in the expansion of english as global language. Revista electrónica Ciencia Digital 2(2), 524-543. Recuperado desde: http://cienciadigital.org/revistacienciadigital2/index.php/CienciaDigital/article/view/117/10 $\underline{8}$

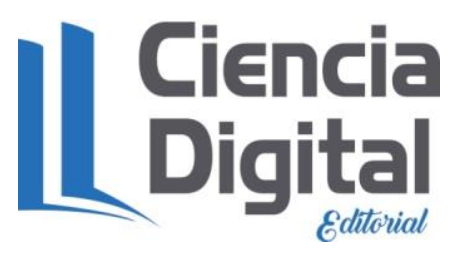

El artículo que se publica es de exclusiva responsabilidad de los autores y no necesariamente reflejan el pensamiento de la Revista Ciencia Digital.

El articulo queda en propiedad de la revista y, por tanto, su publicación parcial y/o total en otro medio tiene que ser autorizado por el director de la Revista Ciencia Digital.
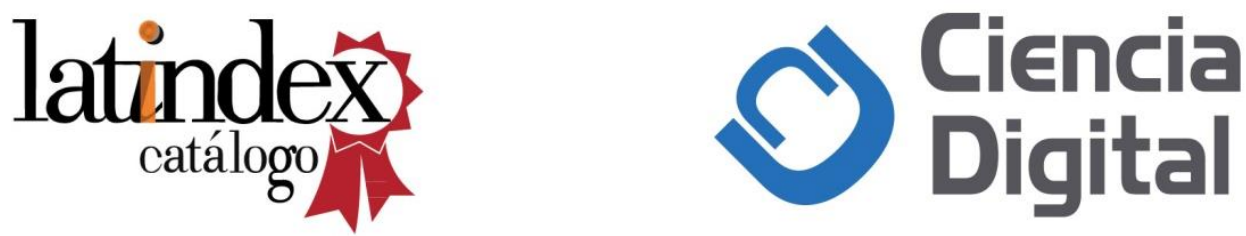